\title{
HUBUNGAN PENDIDIKAN KESEHATAN TENTANG KPSP DENGAN PENGETAHUAN GURU KB TK TENTANG KPSP
}

\author{
Nurun Hikmah ${ }^{1 *}$,Lidia Aditama Putri ${ }^{2}$, Novi Anggraeni ${ }^{3}$, Rizqy Aulia, Rina Arfandiyah ${ }^{5}$
}

\section{Stikes Ngudia Husada}

2 Universitas Muhammadiyah Gresik

\section{Corresponding author:}

Lidia Aditama Putri

Universitas Muhammadiyah Gresik

Email: Liydyaputri@umg.ac.id

\section{Article Info:}

Dikirim:

Ditinjau:

Diterima:

\section{DOI:}

https://doi.org/10.33475/jikmh.v7i2.21

\begin{abstract}
The KPSP (Pre-Development Screening Questionnaire) examination which is carried out for early detection of growth and development of children aged 0-72 months is actually not only the task of health workers, but also people who often interact with children, one of which is Playgroup and Kindergarten teachers. But unfortunately, it's very rare for these playgroup and kindergarten teachers to understand and carry out KPSP examinations for their students. This study aims to analyze the relationship of health education about KPSP with the knowledge of playgroup and kindergarten teachers about KPSP. It was pre-post test design, the sample were taken randomly by simple random sampling on 33 playgroup and kindergarten teachers at Permata Hati Bangkalan and Taman Posyandu Eforbia Bangkalan. The data were analyzed using paired T-test with a significance of $=0.05$ using SPSS. The results showed that there was a relationship between health education about KPSP with the knowledge of Playgroup and Kindergarten teachers about KPSP ( $p$ value $<0.001)$. The average value of teachers knowledge about KPSP has increased before and after health education, from 49.39 to 62.88. It can be concluded that educational activities through health education are effective in increasing the knowledge of Playgroup and Kindergarten teachers about KPSP.
\end{abstract}

Keywords: KPSP, Teachers, Education.

\begin{abstract}
Abstrak
Pemeriksaan KPSP (Kuisioner Pra Skrining Perkembangan) yang dillakukan untuk deteksi dini tumbuh kembang anak usia $0-72$ bulan sejatinya tidak hanya menjadi tugas dari tenaga kesehatan, namun juga orang yang sering berinteraksi dengan anak pun harus melakukannya, yang salah satunya adalah guru KB (Kelompok Bermain) dan TK (Taman Kanak-Kanak). Akan tetapi sayangnya, sangat jarang guru KB dan TK ini yang memahami dan melakukan pemeriksaan KPSP terhadap anak didiknya. Penelitian ini bertujuan untuk menganalisis hubungan pendidikan kesehatan tentang KPSP dengan pengetahuan guru KB TK tentang KPSP. menggunakan SPSS. Hasil penelitian menunjukkan bahwa terdapat hubungan pendidikan kesehatan tentang KPSP dengan pengetahuan guru KB TK tentang KPSP ( $\mathrm{p}$ value $<0,001$ ). Nilai rata-rata pengetahuan guru tentang KPSP mengalami peningkatan sebelum dan sesudah dilakukan pendidikan kesehatan, yaitu dari 49,39 menjadi 62,88. Dapat disimpulkan bahwa kegiatan edukasi melalui pendidikan kesehatan efektif dalam meningkatkan pengetahuan guru KB TK tentang KPSP.Jenis penelitian ini adalah pre-post test design, sampel diambil secara acak dengan simple random sampling pada 33 orang guru KB dan TK di Permata Hati Bangkalan dan Taman Posyandu Eforbia. Data dianalisis dengan menggunakan paired T-Tes dengan signifikasi $\alpha=0,05$
\end{abstract}

Kata Kunci: KPSP, Guru, Penyuluhan 


\section{PENDAHULUAN}

Pertumbuhan dan perkembangan seorang anak sangat penting untuk mendapatkan perhatian yang ekstra, sebab masa masa ini merupakan masa yang krusial sebagai salah satu faktor yang menentukan kesehatan dan kesejahteraan anak pada masa mendatang. Pertumbuhan diartikan sebagai suatu proses dalam bertambahnya jumlah sel, jaringanm dan ukuran tubuh; sedangkan perkembangan diartikan sebagai suatu proses dalam bertambahnya suatu fungsi, struktur, dan kemampuan tubuh yang lebih kompleks (Susanto, 2011). Proses tumbuh kembang tersebut dibagi ke dalam beberapa tahapan yang berdasarkan usia seorang anak, salah satunya adalah pada saat seorang anak berusia $3-6$ tahun yang disebut sebagai anak pra sekolah. Anak usia 3-6 tahun yang notabene telah memasuki masa sekolah KB dan TK masih termasuk ke dalam kelompok anak di masa golden period, yaitu masa penting dari proses tumbuh kembang anak (Kemkes RI, 2016).

Salah satu cara untuk melakukan pemantauan tumbuh kembang anak usia pra sekolah adalah dengan menggunakan Kuisioner Pra Skrining Perkembangan atau yang lebih dikenal dengan KPSP (Depkes RI, 2006). KPSP yang dilakukan setiap 3 bulan sekali ini tidak hanya bermanfaat untuk mengetahui status pertumbuhan dan perkembangan anak, namun juga bermanfaat untuk deteksi dini gangguan tumbuh kembang anak sehingga intervensi dini pun dapat dilakukan dengan maksimal.

Angka kejadian gangguan perkembangan anak di seluruh dunia menurut data dari UNICEF (2012) masih tergolong tinggi yaitu di Amerika Serikat bekisar $12-16 \%$, Thailand $24 \%$, Argentina $22 \%$, dan Indonesia 13-18\%, sekitar 1-3 anak terhambat pertumbuhannya sekitar $40 \%$ berada di daerah pedesaan (Haryanti, Ashom, \& Aeni, 2019). Anak-anak usia prasekolah memiliki beberapa ciri serta tugas perkembangan yang meliputi ketrampilan motorik kasar, motorik halus, bahasa dan sosial. Keinginan yang kuat untuk bermain bersama teman, melakukan penjelajahan atau eskplorasi lingkungan sekitar, melakukan latihan secara berkelompok, sering menirukan orang lain dan sering bertanya merupakan ciri-ciri dari anak usia pra sekolah. Selama periode ini juga terjadi transisi emosi antara orang tua dan anak prasekolah (Wong, D. L., Hockenberry, M. E., Wilson, D., Winkelstein, M. \& Schwartz, 2009). Periode emas anak usia pra sekolah ini tentu saja sangat disayangkan jika dilewatkan begitu saja, di usia 3-6 tahun ini perkembangan kognitif anak sedang sangat pesat hingga mencapai $80 \%$. Oleh karenanya, maka upaya untuk mengoptimalkan perkembangan anak di usia ini harus dilakukan secara maksimal (Apriana, 2009). Tenaga medis, guru di sekolah, orang tua, kader kesehatan, hingga pengasuh anak bisa melakukan upaya upaya tersebut. Untuk itu maka sudah barang tentu mereka harus paham dan terampil dalam melakukan pemeriksaan tumbuh kembang anak.

Pemeriksaan perkembangan anak dengan menggunakan KPSP perlu dilakukan secara teratur dan berkesinambungan untuk dapat melihat status perkembangan anak serta dapat mendeteksi dini adanya gangguan atau penyimpangan perkembangan anak termasuk dalam hal melakukan tindak lanjut terhadap keluhan orang tua mengenai masalah perkembangan anaknya. Apabila kesimpulan dari hasil pemeriksaan menunjukkan adanya penyimpangan perkembangan, maka intervensi dini dapat segera dilakukan sehingga tumbuh kembang anak dapat kembali normal dan/atau penyimpangan perkembangan tersebut kondisinya tidak semakin parah. Kemudian apabila anak tersebut perlu mendapatkan rujukan maka hal tersebut bisa dilakukan sedini mungkin (Kemkes RI, 2016).

Kegiatan pemantauan perkembangan anak dengan KPSP dilakukan secara terkoordinasi oleh berbagai pihak sebagai mitra dari tenaga kesehatan, antara lain orang tua, anggota keluarga, pengasuh, para guru, kader 
kesehatan, tokoh masyarakat, bahkan lembaga swadaya masyarakat. Kehadiran para mitra ini dalam perannya turut serta melakukan pemeriksaan perkembangan pada anak dapat meningkatkan kualitas tumbuh kembang anak usia dini dan membantu anak siap untuk memasuki jejang pendidikan formal pada tingkat yang lebih tinggi (Kemkes RI, 2016). Salah satu mitra yang penting untuk dapat melakukan pemantauan perkembangan anak adalah para guru di sekolah KB dan TK sebab mereka adalah garda terdepan mencetak generasi yang cerdas, mandiri, serta sehat jiwa dan raga.

Para pendidik yaitu guru KB dan TK merupakan salah satu mitra tenaga kesehatan dalam melakukan kegiatan stimulasi, intervensi, dan deteksi dini tumbuh kembang anak yang salah satunya dilakukan dengan menggunakan KPSP. Akan tetapi sayangnya, selama ini sosialisasi tentang penggunaan KPSP di kalangan guru $\mathrm{KB}$ dan TK di Bangkalan masih sangat minim. Beberapa di antaranya adalah yang terjadi di KB TK Permata Hati Bangkalan dan Taman Posyandu Eforbia Bangkalan, para guru di dua sekolah tersebut tidak tahu bagaimana penggunaan KPSP karena selama ini tidak pernah mendapatkan edukasi dari tenaga kesehatan di wilayahnya.

Tujuan dari penelitian ini adalah untuk menganalisis hubungan hubungan pendidikan kesehatan tentang KPSP (Kuesioner Pra Skrining Perkembangan) dengan Pengetahuan Guru KB TK tentang KPSP.

\section{METODE}

Jenis penelitian analitik observasional dengan pendekatan pre-post test design. Populasi dalam penelitian ini adalah seluruh guru KB (Kelompok Bermain) dan TK (Taman Kank-Kanak) di Permata Hati Bangkalan dan Taman Posyandu Eforbia Bangkalan, kemudian sebanyak 33 guru terpilih menjadi sampel secara acak menggunakan simple random sampling.
Variabel independen dalam penelitian ini adalah pendidikan kesehatan, sedangkan variabel dependen dalam penelitian ini adalah pengetahuan guru tentang KPSP (Kuisioner Pra Skrining Perkembangan),

Penelitian ini dilakukan pada bulan Januari - Maret 2021. Responden penelitian menjawab pertanyaan kuisioner tentang teori KPSP, setelahnya responden diberikan pendidikan kesehatan oleh peneliti dan kemudian diberikan kesempatan kembali untuk menjawab pertanyaan kuisioner tersebut.

Pendidikan kesehatan dilakukan dengan metode ceramah dan diskusi tentang KPSP, kemudian dilanjutkan dengan pemberian demonstrasi tentang cara melakukan KPSP. Media yang digunakan adalah power point dan alat permainan edukatif.

Analisis data dilakukan secara univariat dengan menggunakan tabel frekuensi dan bivariate untuk menganalisis hubungan pendidikan kesehatan dengan pengetahuan guru KB TK tentang KPSP menggunakan uji statistik Paired T-Test dengan SPSS (signifikansi $0,05)$.

\section{HASIL DAN PEMBAHASAN}

Usia, tingkat pendidikan, lama bekerja, dan jabat responden dapat dijelaskan pada tabel 1.

Tabel 1. Karakteristik Responden

\begin{tabular}{lcc}
\hline \multicolumn{1}{c}{ Variabel } & $\begin{array}{c}\text { Jumlah } \\
(\mathbf{n})\end{array}$ & $\begin{array}{c}\text { Persentase } \\
(\mathbf{\%})\end{array}$ \\
\hline Usia & & \\
21-25 tahun & 4 & 12,1 \\
26-30 tahun & 22 & 66,7 \\
31-35 tahun & 5 & 15,1 \\
36-40 tahun & 2 & 6,1 \\
Tingkat Pendidikan & & \\
S1 PGPAUD & 11 & 33,3 \\
S1 PGTK & 18 & 54,5 \\
S1 PG & 3 & 9,1 \\
S2 PG & 1 & 3,0 \\
Lama Bekerja & & \\
1-5 tahun & 20 & 60,6 \\
6-10 tahun & 13 & 39,4
\end{tabular}


Guru KB

Guru TK A

Guru TK B

Berdasarkan tabel 1 dapat dilihat bahwa sebagian besar guru di TK Permata Hati dan Taman PAUD Eforbia Bangkalan berusia sekitar 26-30 tahun yaitu sebanyak 22 orang $(66,7 \%)$. Sedangkan berdasarkan tingkat pendidikan sebagian besar merupakan Iulusan Srata 1 Pendidikan Guru Taman Kanak-Kanak yaitu sebanyak 18 orang $(54,5 \%)$. Para guru tersebut sebagian besar telah bekerja selama 1-5 tahun yaitu sebanyak 20 orang $(60,6 \%)$.

Tabel 1 juga menunjukkan bahwa hampir setengahnya guru di TK Permata Hati dan Taman Posyandu Eforbia Bangkalan mengajar di tingkat TK A yaitu bagi anak usia 4-5 tahun, hal ini tercatat sebanyak 12 orang guru $(36,3 \%)$ yang mengajar di kelas TK $A$.

Tabel 2. Rata-Rata Pengetahuan Guru Tentang KPSP Sebelum dan Sesudah Diberikan Pendidikan Kesehatan

\begin{tabular}{ccccc}
\hline $\begin{array}{c}\text { Pengetahuan } \\
\text { Guru } \\
\begin{array}{c}\text { Tentang } \\
\text { KPSP }\end{array}\end{array}$ & Nilai & $\begin{array}{c}\text { Nilai } \\
\text { minimum }\end{array}$ & $\begin{array}{c}\text { Rata- } \\
\text { maksimum }\end{array}$ & Rata \\
\hline Pre Test & 15 & 80 & 49,39 & 12,976 \\
Post Test & 40 & 80 & 62,88 & 12,376
\end{tabular}

Tabel 2 menunjukkan bahwa terjadi peningkatan nilai minimum sebelum dan sesudah diberikan pendidikan kesehatan tentang KPSP, yaitu dari nilai 15 pada saat pre-test kemudian meningkat menjadi nilai 40 setelah post-test. Sedangkan nilai tertinggi (maksimum) dari para guru sebelum maupun sesudah diberikan pendidikan kesehatan sama, yaitu 80 .

Pada tabel 2 juga menunjukkan bahwa terdapat kenaikan nilai rata-rata dari para guru di TK Permata
Hati dan Taman Posyandu Eforbia sebelum dan sesudah diberikan penyuluhan kesehatan tentang KPSP, dimana sebelum diberikan pendidikan kesehatan nilai rata-rata pengetahuan tentang KPSP guru adalah sebear 49,39, kemudian setelah diberikan pendidikan kesehatan nilai rata-rata pengetahuan guru tentang KPSP meningkat menjadi 62,88 .

\section{Tabel 3. Tabulasi Silang Tingkat Pengetahuan Guru Tentang KPSP Sebelum dan Sesudah Diberikan Pendidikan Kesehatan}

\begin{tabular}{ccccc}
\hline \multirow{2}{*}{$\begin{array}{c}\text { Tingkat } \\
\text { Pengetahuan }\end{array}$} & \multicolumn{2}{c}{ Pre Test } & \multicolumn{2}{c}{ Post Test } \\
\cline { 2 - 5 } & $\mathrm{N}$ & $\%$ & $\mathrm{~N}$ & $\%$ \\
\hline Baik & 14 & 42,4 & 25 & 75,8 \\
Tidak baik & 19 & 57,6 & 8 & 24,2 \\
\hline Jumlah & 33 & 100 & 33 & 100 \\
\hline
\end{tabular}

Berdasarkan tabel 3 menunjukkan bahwa dari 33 (100\%) guru yang belum diberikan pendidikan kesehatan tentang KPSP sebagian besar memiliki tidak baik tentang KPSP yaitu sebesar 57,6\%. Guru tersebut kemudian diberikan pendidikan kesehatan tentang KPSP sehingga kemudian ditemukan hasilnya bahwa guru yang telah diberikan pendidikan kesehatan sebagian besar memiliki tingkat pengetahuan yang baik sebesar 75,8\%. Hasil tersebut menunjukkan bahwa tingkat pengetahuan guru tentang KPSP meningkat setelah diberikan pendidikan kesehatan. 
Tabel 4. Analisis Tingkat Pengetahuan Guru Tentang KPSP Sebelum dan Sesudah Diberikan Pendidikan Kesehatan

\begin{tabular}{cccccc} 
Pengetah & \multicolumn{5}{c}{ Paired Samples Test } \\
u-an & Confidence \\
\cline { 2 - 6 } $\begin{array}{c}\text { Sebelum } \\
\text { dan }\end{array}$ & Mea & SD & $\begin{array}{c}\text { Conterval (Cl } \\
\text { Intery }\end{array}$ & $\mathrm{P}$ \\
Sesudah & 48,6 & \multicolumn{5}{c}{$95 \%)$} \\
Perlakuan & 12,7 & 44,0 & 53,1 & $<0,001$ \\
& 1 & 7 & 8 & 4 & \\
\hline
\end{tabular}

Berdasarkan hasil uji statistik seperti yang digambarkan dalam tabel 4, maka dapat disimpulan bahwa terdapat hubungan antara tingkat pengetahuan guru tentang KPSP sebelum dan sesudah diberikan pendidikan kesehatan, yaitu dengan nilai $p<0,001 \leq 0,05$.

Pengetahuan seseorang merupakan hasil tahu yang terjadi setelah orang tersebut melakukan penginderaan dari objek tertentu. Penginderaan tersebut diperoleh melalui panca inderanya, yang meliputi indera penglihatan, pendengaran, perasa, peraba, dan indera penciuman. Dari 5 (lima) indera tersebut, indera penglihat dan pendengar manusialah yang berperan sangat penting dalam pembentukan pengetahuan baru, ini artinya pengetahuan manusia sebagian besar diperolehnya melalui mata dan telinga (Notoatmodjo, 2012). Pengetahuan berperan penting terhadap tumbuhnya sikap dan perilaku manusia, menurut teori Bloom (1956) pengetahuan adalah salah satu komponen yang membentuk perilaku baru seseorang dan dengan pengetahuan seseorang kemudian bisa memiliki pertimbangan tentang caranya bersikap dan berperilaku (Bloom \& Benjamin, 1956).
Pengetahuan seseorang bisa diukur dengan cara menilai kemampuannya dalam memberikan penjelasan tentang hal-hal yang dia ketahui dalam bentuk bukti dan/atau jawaban secara lisan maupun tulisan. Bukti dan/atau jawaban yang diberikan oleh seseorang tersebut adalah suatu reaksi dari stimulus yang bisa berupa pertanyaan lisan atau tertulis (Intarti, 2019; Notoatmodjo, 2012).

Berdasarkan hasil kuisioner yang telah diberikan kepada guru dengan skala penilaian dari 0-20 diketahui bahwa pengetahuan guru tentang KPSP sebelum diberikan pendidikan kesehatan rata-rata adalah 49,39 (tabel 2). Nilai rata-rata tersebut termasuk rendah karena tidak sampai 50\% dari pertanyaan kuisioner yang dapat dijawab oleh guru. Penyebab dari rendahnya nilai dari guru tersebut adalah karena sebagian besar guru tidak pernah melakukan pengukuran tumbuh kembang pada siswa didiknya menggunakan KPSP serta para guru tersebut sebelumnya tidak pernah pula mendapatkan penyuluhan/pendidikan kesehatan tentang KPSP.

Setelah para guru tersebut diberikan pendidikan kesehatan tentang KPSP, dapat terlihat terjadinya peningkatan nilai rata-rata dari pengetahuan guru tersebut yaitu menjadi 62,88 (tabel 3). Artinya, nilai rata-rata tersebut telah meningkat lebih dari $50 \%$ dari pertanyaan kuisioner yang dapat di jawab oleh guru.

Hasil penelitian ini menunjukkan bahwa terjadi kenaikan nilai rata-rata guru sebelum dan sesudah diberikan pendidikan kesehatan tentang KPSP (49,39 menjadi 62,88), selisih nilai tersebut adalah sebesar 13,49 . 
Informasi yang didapatkan seseorang melalui pemberian penyuluhan, KIE, dan/atau pendidikan kesehatan pada seseorang dapat meningkatkan pengetahuannya terhadap sesuatu. Hasil penelitian ini sejalan dengan penelitian yang dilakukan oleh Rahayu \& Purnamasari (2019) bahwa terjadi peningkatan nilai rata-rata dari pengetahuan guru tentang KPSP setelah dilakukan penyuluhan $(8,945$ menjadi 15,75). Selain itu, penelitian yang dilakukan oleh Ina \& Betan (2017) juga menunjukkan hal yang sama yaitu terjadi kenaikan nilai rata-rata dari 18,8 menjad 82,4 setelah guru diberikan penyuluhan kesehatan.

Tingkat pengetahuan tentang KPSP sebelum dan sesudah diberikan pendidikan kesehatan juga mengalami peningkatan. Pengetahuan guru sebelum diberikan pendidikan kesehatan yang baik sebesar $42,4 \%$ dan tidak baik sebesar 57,6\%. Kemudian setelah guru diberikan pendidikan kesehatan tentang KPSP diketahui tingkat pengetahuan baik meningkatmenjadi 75,8\% dan pengetahuan tidak baik menurun menjadi $24,2 \%$

Notoatmojo (2012) menyatakan bahwa

pengetahuan seseorang salah satunya dipengaruhi oleh faktor usia dan pendidikan. Semakin tinggi usia seseorang maka tingkat kematangannya dalam berpikir dan bekerja juga semakin tinggi. Begitu pula dengan pendidikan seseorang, semakin tinggi tingkat pendidikannya maka kemampuannya dalam menyerap informasi menjadi semakin tinggi sehingga semakin baik pula tingkat

pengetahuannya. Hal tersebut rupanya sejalan dengan penelitian ini, dluruh guru telah menempuh pendidikan tinggi yaitu pada jenjang strata 1 dan strata 2, serta sebagian besar besar dari mereka telah memiliki usia dewasa yaitu $66,7 \%$ berusia $26-$ 30 tahun.

Hasil penelitian ini juga sejalan dengan penelitian yang dilakukan oleh Purwati, Sutini, Apriliawati, Rayasari, \& Astuti (2019) yang menunjukkan bahwa terjadi peningkatan pengetahuan tentang KPSP sebelum dan sesudah penyuluhan. Hasil uji statistik dalam penelitian ini yang dilakukan untuk menganalisis hubungan pendidikan kesehatan terhadap pengetahuan guru tentang KPSP diperoleh hasil nilai $\mathrm{p}<0,001 \leq \alpha 0,05$. Artinya terdapat hubungan yang signifikan dari pengetahuan guru tentang KPSP sebelum dan sesudah diberikan pendidikan kesehatan di KB TK Permata Hati dan Taman Posyandu Eforbia Bangkalan.

Edukasi atau pendidikan adalah segala upaya atau usaha yang direncanakan dalam rangka mempengaruhi seseorang atau masyarakat sehingga melakukan sesuatu yang diharapkan oleh pelaku pendidikan (Notoatmodjo, 2012). Berdasarkan hal itu, maka pengetahuan seseorang bisa didapatkan melalui berbagai macam pengalaman belajar seseorang yang diantaranya melalui kegiatan edukasi. Faktor yang sangat berpengaruh terhadap keberhasilan dari kegiatan edukasi melalui pendidikan kesehatan yang dilakukan antara lain pemilihan metode. Pada penelitian ini, metode pendidikan kesehatan yang dilakukan selain menggunakan ceramah dengan media power point dan leaftlet, juga dilakukan kegiatan demonstrasi pemeriksaan KPSP kepada anak didik sehingga 
guru menggunakan banyak panca inderanya untuk menyerap infomasi baru yang diterimanya.

Menurut Mar'at (2008) dan Notoatmodjo, (2012) menyatakan bahwa semakin banyak indera seseorang yang digunakan untuk menerima sebuah stimulus atau informasi, maka semakin banyak dan semakin jelas pula pengetahuan yang akan diperolehnya. Menurut Prasida, Maftuchah, \& Mayangsari (2015) dalam penelitiannya menyatakan bahwa pendidikan kesehatan dengan melakukan penyuluhan bisa meningkatkan pengetahuan seseorang, apalagi jika hal ini dilakukan dengan menggunakan alat peraga dan diskusi tanya jawab dengan peserta melakui kegiatan demonstrasi.

Pemeriksaan deteksi dini tumbuh kembang anak atau yang lebih dikenal dengan pemeriksaan KPSP ini tidak hanya ditujukan bagi petugas kesehatan saja seperti bidan, dokter, perawat, penyuluh kesehatan masyarakat, ahli gizi dan sebagainya, namun pemeriksaan KPSP ini juga ditujukan bagi para petugas di sektor lainnya seperti para guru di sekolah, orang tua, pengasuh, dan sebagainya yang sehari-hari berkecimpung dengan anak usia dini. Artinya, mereka pun juga seharusnya bisa melakukan tugas mendeteksi dini tumbuh kembang anak, tidak melulu harus menunggu petugas kesehatan yang melakukannya. Oleh karenanya, pengetahuan mereka tentang KPSP juga perlu ditingkatkan agar tumbuh sikap positif tentang KPSP dan mendorong mereka untuk melakukan deteksi dini tumbuh kembang menggunakan KPSP.
Para guru KB dan TK notabene merupakan para pendidik terpelajar yang dekat dengan anak didiknya sehingga ia tidak hanya bertanggung jawab atas pendidikan anak didiknya namun juga sekaligus bertanggung jawab terhadap pertumbuhan dan perkembangan dari anak didiknya. Apabila tumbuh kembang anak optimal maka optimal pula kecerdasan yang dimiliki anak tersebut. Oleh karenanya, adanya pengetahuan yang baik tentang KPSP beserta cara melakukan pemeriksaan tumbuh kembag menggunakan KPSP akan mendorong guru KB dan TK untuk lebih akif dalam pemeriksaan pertumbuhan dan perkembangan anak didiknya, lebih jeli dalam mendeteksi penyimpangan tumbuh kembang yang terjadi pada anak didiknya, dan tepat dalam melakukan stimulasi tumbuh kembang dan penanganan apabila terjadi penyimpangan tumbuh kembang pada anak didiknya.

\section{KESIMPULAN}

Terdapat hubungan pendidikan kesehatan tentang KPSP (Kuisioner Pra Skrining Perkembangan) dengan pengetahuan guru KB TK tentang KPSP $(\mathrm{p}<0,001)$. Terdapat kenaikan nilai rata-rata pengetahuan pada guru tentang KPSP sebelum dan setelah diberikan pendidikan kesehatan yaitu sebesar 13,49\%, ini artinya pendidikan kesehatan yang dilakukan dengan ceramah dan demonstrasi mengenai KPSP efektif dalam meningkatkan pengetahuan guru KB TK tentang KPSP. 


\section{UCAPAN TERIMA KASIH}

Tim peneliti mengucapkan terimakasih kepada Universitas Muhammadiyah Gresik dan STIKES Ngudia Husada Madura yang telah memberikan

\section{DAFTAR RUJUKAN}

Apriana, R. (2009). Hubungan Pendidikan Anak Usia Dini (PAUD) dengan Perkembangan Kognitif Anak Usia Pra Sekolah di Kelurahan Tinjomoyo Kecamatan Banyumanik Semarang. Retrieved from eprints.undip.ac.id/9475/1/articel.pdf

Bloom, \& Benjamin, S. (1956). Taxonomy of Educational Objectives: The Classification of Educational Goals, Handbook I Cognitive Domain. New York: Longmans, Green and Co.

Depkes RI. (2006). Pedoman Pelaksanaan Stimulasi, Deteksi, dan Intervensi Dini Tumbuh Kembang Anak. Jakarta: Bakti Husada.

Haryanti, D., Ashom, K., \& Aeni, Q. (2019). Gambaran Perilaku Orang Tua Dalam Stimulasi Pada Anak Yang Mengalami Keterlambatan Perkembangan Usia 0-6 Tahun. Jurnal Keperawatan Jiwa, 6(2), 64. https://doi.org/10.26714/jkj.6.2.2018.64-70

Ina, A., \& Betan, M. O. (2017). Influence of Health Education on Early Detection of Child Development Under five years of age Against Increasing Maternal Knowledge and Skills in Early Detection of Child Development at Sikumana Community Health Center , Kupang City. Jurnal Indo Kesehatan, 15(1), 1-14.

Intarti, W. D. (2019). Pengaruh KIE terhadap Tingkat Pengetahuan Guru PAUD tentang Stimulasi Kecerdasan Otak Anak Usia Dini. Jurnal Kebidanan Harapan Ibu Pekalongan, 6, 202-212. https://doi.org/10.37402/jurbidhip.vol6.iss2.56
Kemkes RI. (2016). Pedoman Pelaksanaan Stimulasi, Deteksi dan Intervensi Dini Tumbuh Kembang Anak di Tingkat Pelayanan Kesehatan Dasar. Jakarta: Departemen Kesehatan Republik Indonesia.

Mar'at. (2008). Psikologi Perkembangan. Bandung: PT Remaja Rosdakarya.

Notoatmodjo. (2012). Promosi Kesehatan dan Ilmu Perilaku. Jakarta: Rineka Cipta.

Prasida, Maftuchah, \& Mayangsari. (2015). Pengaruh Penyuluhan Tentang KPSP Terhadap Pengetahuan Guru Di Paud Taman Belia Semarang. Lembaga Penelitian Dan Pengabdian Kepada Masyarakat Universitas Muhammadiyah Semarang, 570-576. Retrieved from https://jurnal.unimus.ac.id/index.php/psn12012010 /article/view/1638

Purwati, N. H., Sutini, T., Apriliawati, A., Rayasari, F., \& Astuti, A. (2019). Peningkatan pengetahuan orangtua dan screening tumbuh kembang anak. Prosiding Seminar Nasional Pengabdian Masyarakat LPPM UMJ, (September 2019).

Rahayu, C. D., \& Purnamasari, I. (2019). Pelatihan SDIDTK untuk Meningkatkan Pengetahuan Guru PAUD dalam Melakukan SDIDTK di Kabupaten Wonosobo. Jurnal Penelitian Dan Pengabdian Kepada Masyarakat UNSIQ, 6(1), 31-36. https://doi.org/10.32699/ppkm.v6i1.498

Susanto, A. (2011). Perkembangan Anak Usia Dini: Pengantar dalam Berbagai Aspeknya. Jakarta: Prenada Media Group. 
Wong, D. L., Hockenberry, M. E., Wilson, D., Winkelstein, M. \& Schwartz, P. (2009). Buku Ajar Keperawatan Pediatrik (6th ed.). Jakarta: EGC.

Cite this article as: Hikmah, N., Putri, L, A., Anggraeni, N., Aulia R., Arfandiyah R. (2021). Hubungan Pendidikan Kesehatan Tentang KPSP (Kuesioner Pra Skrining Perkembangan) Dengan

Pengetahuan Guru KB TK Tentang KPSP. Jurnal Ilmiah Media Husada. 10(2), 115-123.

https://doi.org/10.33475/jikmh.v7i2.21 